\title{
The Many for One or One for the Many? Reading Mark 10:45 in the Roman Empire
}

\author{
Matthew Thiessen \\ McMaster University
}

\begin{abstract}
You know that those who are supposed to rule the gentiles lord it over them, and their great ones exercise authority over them. But it is not so among you, but whoever desires to be great among you will be your servant. And whoever desires to be first among you will be a slave of all. For the Son of Man came not to be served but to serve and to give his life as a ransom for many. (Mark 10:42-45)

Mark, Peter's follower [sectator], while Peter was preaching [praedicante] publicly the Gospel at Rome in the presence of certain of Caesar's equestrians [equitubus, i.e., members of the equestrian order] and was putting forward many testimonies concerning Christ, being requested [petitus] by them that they might be able to commit to memory the things that were being spoken, wrote from the things that were spoken by Peter the Gospel that is called, "According to Mark." (Clement of Alexandria)
\end{abstract}

In his expository remarks on 1 Pet 5:13, Clement of Alexandria portrays Mark as the preserver of the apostle Peter's gospel proclamation to those who not only dwell in Rome, but also belong to the Roman elite. ${ }^{1}$ In this regard, Clement's testimony

${ }^{1}$ Quotation, including bracketed material, taken from C. Clifton Black, Mark: Images of an Apostolic Interpreter (Studies on Personalities of the New Testament; Columbia: University of South Carolina Press, 1994) 139. As Black clarifies, Clement's Adumbrationes are preserved in the $6^{\text {th }}$-cent. Latin translation of Cassiodorus.

HTR 109:3 (2016) 447-466 
coincides with the near unanimous voice of the Church Fathers, who locate the composition of the Gospel of Mark in the city of Rome (e.g., Irenaeus Haer. 3.1.1; Eusebius Hist. eccl. 2.15.2). ${ }^{2}$

Despite this early unanimity, modern interpreters continue to debate the gospel's provenance. While the majority continues to locate Mark in Rome, ${ }^{3}$ others have suggested Galilee ${ }^{4}$ or Syria. ${ }^{5}$ Still others argue that Mark provides too little information to be able to associate his gospel with one particular city or region. ${ }^{6}$ What this debate has at times obscured, though, is the fact that, no matter where the Gospel of Mark was written and to whom it was originally addressed, its audience and author dwelt within the Roman Empire. ${ }^{7}$ As Michael Peppard argues, "Whether or not Mark was written in the city of Rome, it was written in the context of empire." ${ }^{8}$ Peppard's own work demonstrates the fruitfulness of reading Mark's

\footnotetext{
${ }^{2}$ It appears that John Chrysostom was the first church father to place Mark outside of Rome, claiming that he wrote in Egypt (Hom. Matt. 1.7). For a full discussion of the patristic evidence, see Black, Mark: Images, 77-182.

${ }^{3}$ E.g., Martin Hengel, Studies in the Gospel of Mark (London: SCM, 1985) 1-30; Donald Senior, “"With Swords and Clubs ... ': The Setting of Mark's Community and His Critique of Abusive Power," BTB 17 (1987) 10-20; Brian J. Incigneri, The Gospel to the Romans: The Setting and Rhetoric of Mark's Gospel (BIS 65; Leiden: Brill, 2003) 59-115; and Adam Winn, The Purpose of Mark's Gospel: An Early Christian Response to Imperial Propaganda (WUNT 2/245; Tübingen: Mohr Siebeck, 2008).

${ }^{4}$ See Willi Marxsen, Mark the Evangelist: Studies in the Redaction History of the Gospel (Nashville: Abingdon, 1969) 54-116; Ched Myers, Binding the Strong Man (Maryknoll, NY: Orbis, 1988) 53-54; and Hendrika N. Roskam, The Purpose of the Gospel of Mark in its Historical and Social Context (NovTSup 114; Leiden: Brill, 2004) 75-114.

${ }^{5}$ E.g., Howard Clark Kee, Community of the New Age: Studies in Mark's Gospel (Macon, GA: Mercer University Press, 1983) 77-105; Gerd Theissen, The Gospels in Context: Social and Political History in the Synoptic Tradition (Minneapolis: Fortress, 1991) 235-89; Joel Marcus, "The Jewish War and the Sitz im Leben of Mark," JBL 111 (1992) 441-62; idem, Mark 1-8: A New Translation with Introduction and Commentary (AB 27; New York: Doubleday, 2000) 28-37; and Ludger Schenke, Das Markusevangelium: Literarische Eigenart-Text und Kommentierung (Stuttgart: Kohlhammer, 2005) 41.

${ }^{6}$ For instance, Dwight N. Peterson, The Origins of Mark: The Markan Community in Current Debate (BIS 48; Leiden: Brill, 2000), and C. Clifton Black, Mark (ANTC; Nashville: Abingdon, 2011) 30. Going one step further, Richard Bauckham argues that the gospels were not intended for specific communities, and concludes that the search for the Markan community is misguided ("For Whom Were the Gospels Written?" in idem, ed., The Gospel for all Christians: Rethinking the Gospel Audiences [Grand Rapids: Eerdmans, 1998] 9-48). Nonetheless, Margaret M. Mitchell has provided compelling patristic evidence that even the earliest interpreters of the gospels thought that they were connected to specific communities ("Patristic Counter-evidence to the Claim that "the Gospels were Written for all Christians,"” NTS 51 [2005] 36-79).

${ }^{7}$ Alberto de Mingo Kaminouchi, "But it is Not So Among You": Echoes of Power in Mark 10.32-45 (JSNTSup 249; London: T\&T Clark, 2003) 161.

${ }^{8}$ Michael Peppard, The Son of God in the Roman World: Divine Sonship in Its Social and Political Context (Oxford: Oxford University Press, 2011) 91. Similarly, Adam Winn, "Tyrant or Servant? Roman Political Ideology and Mark 10.42-45," JSNT 36 (2014) 325-52, at 330 n. 14.
} 
"son of God" language (as well as Mark's depiction of Jesus's baptism) within this imperial context. ${ }^{9}$ In this sense, Clement's testimony is not so farfetched: the Gospel of Mark addresses those living in the Roman Empire and who are, therefore, to varying degrees knowledgeable of Roman political and theological ideology. ${ }^{10}$

This article seeks to apply this basic insight to Mark 10:45, a passage in which the Markan Jesus claims that the Son of Man came to serve, not to be served, and to give his life as a ransom for many ( $\lambda u ́ \tau \varrho o v ~ \alpha \dot{v} \tau \grave{\imath} \pi 0 \lambda \lambda \omega \hat{\omega}) .{ }^{11}$ This explicit theological reflection upon the significance of Jesus's death is exceedingly rare in the Synoptic Gospels and thus has occasioned considerable scholarly debate. What precisely does Mark mean to signify by identifying Jesus's death with a $\lambda$ ú @oov ${ }^{12}$ While interpreters have proposed numerous contexts within which to understand best the Markan Jesus's claim that his death served as a ransom for many, I believe that David Seeley correctly argues that Greco-Roman rulership discourses provide a particularly fruitful context for interpreting the ransom saying. I will argue that portrayals of the Emperor Otho's noble suicide, previously unappreciated evidence from Seneca's De clementia, which advises Emperor Nero not to worry about the many who sacrifice their lives on his behalf, and broader themes in Greco-Roman rulership discourses, which frequently promote a hierarchy that values the life of the ruler over the many lives of the ruled, provide the most productive context for understanding this verse, and show that Mark intends to repudiate one GrecoRoman rulership discourse.

${ }^{9}$ Peppard, Son of God, 86-131. See also, Adela Yarbro Collins, "Mark and His Readers: The Son of God among Greeks and Romans," HTR 93 (2000) 85-100.

${ }^{10}$ See Craig A. Evans, "Mark's Incipit and the Priene Calendar Inscription: From Jewish Gospel to Greco-Roman Gospel," JGRChJ 1 (2000) 67-81.

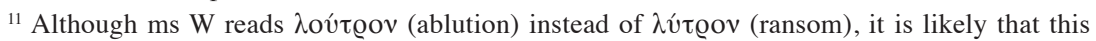
reading arose due to an unintentional scribal modification.

${ }^{12}$ Some scholars argue that the saying goes back to the historical Jesus. See, for instance, Peter Stuhlmacher, "Existenzvertretung für die Vielen: Mk. 10,45 (Mt. 20,28)," in Werden und Wirken des alten Testament: Festschrift für Claus Westermann zum 70. Geburtstag (ed. Rainer Albertz et al.; Göttingen: Vandenhoeck \& Ruprecht, 1980) 412-27; Robert H. Gundry, Mark: A Commentary on His Apology for the Cross (Grand Rapids: Eerdmans, 1993) 588-89; and Craig A. Evans, Mark 8:27-16:20 (WBC 34B; Nashville: Thomas Nelson, 2001) 114-15. Others, rightly to my mind, argue against its authenticity. See, for instance, Rudolf Bultmann, The History of the Synoptic Tradition (trans. John Marsh; New York: Harper \& Row, 1963) 143-44; Rudolf Pesch, Das Markusevangelium (2 vols.; HTKNT 2; Freiburg: Herder, 1976-1977) 2:162-67; and Jürgen Roloff, “Anfänge der soteriologischen Deutung des Todes Jesu (Mk. X.45 und Lk. XXII.27),” NTS 19 (1972-1973) 38-64. 


\section{The Status Quaestionis on Ransom Language in Mark 10:45}

Most scholars argue that Jesus's portrayal of the serving Son of Man in Mark 10:43-45 comes from Deutero-Isaiah's suffering servant. ${ }^{13}$ For instance, Joel Marcus lists a number of parallels between Isa 53:11-12 LXX and Mark 10:43-45. ${ }^{14}$ First, Mark's Jesus states that the Son of Man did not come to be served but to

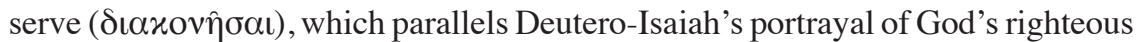

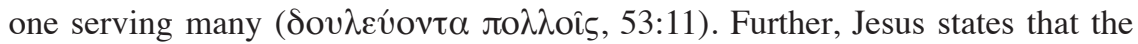

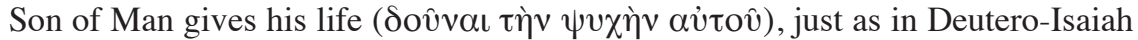

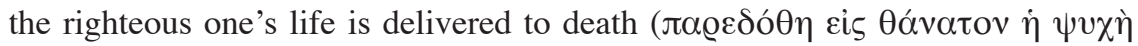

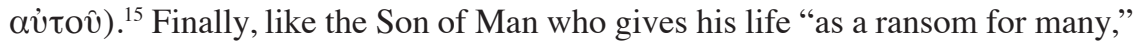
so, too, the righteous one of Isa 53:12 bears "the sin of many" and is "handed over on account of their sins." The general importance of Isaiah for Mark's presentation of Jesus's life strengthens the possibility that Mark alludes to Isaiah at this point. ${ }^{16}$

Nonetheless, those who are skeptical of Isa 53's supposed influence on Mark 10:43-45 argue that the verbal correspondences between Isaiah and Mark appear underwhelming: Isa 53:11-12 shares a number of words with Mark 10:44-45-

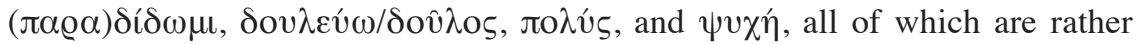
common. ${ }^{17}$ While these agreements at the linguistic level might signify an allusion

${ }^{13}$ For example, Joachim Jeremias, "Das Lösegeld für Viele (Mk 10,45)," Judaica 3 (19471948) 249-64; Alfred Suhl, Die Funktion der alttestamentlichen Zitate und Anspielungen im Markusevangelium (Gütersloh: Gütersloher Verlagshaus, 1965) 114-20; W. J. Moulder, "The Old Testament Background and the Interpretation of Mark 10.45," NTS 24 (1977-1978) 120-27; Joachim Gnilka, Das Evangelium nach Markus (2 vols.; EKKNT 2/2; Neukirchen-Vluyn: Neukirchener Verlag, 1979) 2:104; Stuhlmacher, "Existenzvertretung für die Vielen"; Werner Grimm, Weil Ich dich Liebe: Die Verkündigung Jesu und Deuterojesaja (ANTJ 1; Bern: Lang, 1981) 255; and Rikki E. Watts, "Jesus' Death, Isaiah 53, and Mark 10:45: A Crux Revisited," in Jesus and the Suffering Servant: Isaiah 53 and Christian Origins (ed. William H. Bellinger Jr. and William R. Farmer; Harrisburg, PA: Trinity Press International, 1998) 125-51.

${ }^{14}$ Joel Marcus, Mark 8-16: A New Translation with Introduction and Commentary (AB 27A; New Haven: Yale University Press, 2009) 753.

${ }^{15}$ Although Isa 53:10 also uses the verb $\delta i ́ \delta \omega \mu$ and the noun $\psi v \chi \eta ́$, the verb is a second-person plural subjunctive, and the soul or life in view takes the second-person plural possessive.

${ }^{16}$ See Joel Marcus, The Way of the Lord: Christological Exegesis of the Old Testament in the Gospel of Mark (SNTW; Edinburgh: T\&T Clark, 1993), and Rikki E. Watts, Isaiah's New Exodus and Mark (WUNT 2/88; Tübingen: Mohr Siebeck, 1997).

${ }^{17}$ See C. K. Barrett, “The Background of Mark 10:45," in New Testament Essays: Studies in Memory of Thomas Walter Manson (ed. A. J. B. Higgins; Manchester: Manchester University Press, 1959) 1-18; Morna D. Hooker, Jesus and the Servant: The Influence of the Servant Concept of Deutero-Isaiah in the New Testament (London: SPCK, 1959) 78; Max Wilcox, "On the RansomSaying in Mark 10.45c, Matt 20.28c," in Geschichte-Tradition-Reflexion: Festschrift für Martin Hengel zum 70. Geburtstag (ed. Hermann Lichtenberger et al.; Tübingen: Mohr [Siebeck], 1996) 173-86; and Sharyn Dowd and Elizabeth Struthers Malbon, “The Significance of Jesus' Death in Mark: Narrative Context and Authorial Audience," JBL 125 (2006) 271-97, at 283-85. 
to Isa 53:11-12, the collective volume of the echo created by these commonplace words might not have been loud enough for Mark's readers to hear, even if Mark had intended them to do so. ${ }^{18}$ Most importantly, Isa 53:11-12 lacks the ransom language ( $\lambda$ út@ov) which Mark uses.

Attempting to address this latter issue, Werner Grimm and Peter Stuhlmacher have argued that Mark's ransom language comes from Isa 43:3-4, a passage in

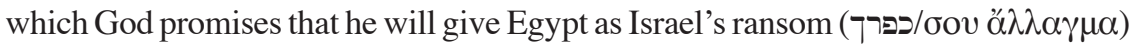
and "a person in place of you, and peoples for your life." While the concept of exchange exists here, there is little in the way of verbal parallels. The only words

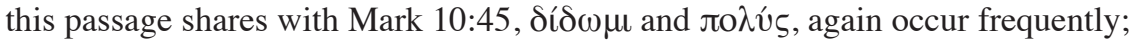
although the MT contains the noun כפר, which can be translated as "ransom," the LXX translation of Isa 43:3-4 lacks $\lambda$ ú @@ov language. ${ }^{19}$

While Mark may allude to Isa 53:11-12, I agree with Adela Yarbro Collins, who argues that this allusion does not fully illuminate Mark's use of $\lambda$ ú $\varrho o v .{ }^{20}$ Consequently, she appeals to inscriptional evidence from Asia Minor to determine "how, in the Roman imperial period, Christians familiar with Hellenistic cultic traditions would have understood the saying," ${ }^{21}$ documenting two inscriptions that commemorate transactions in which people give gifts within a cultic setting in order to remedy guilt. She points to a mid-second century CE inscription which states, "Alexander, son of Thalouse, with Julius and his sister paid to the god Men

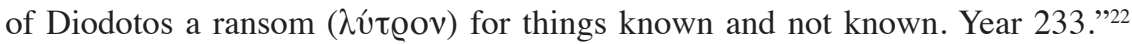
Similarly, the second inscription reads: "A female slave of the village of the Keryzeis [is dedicated] to [Men] Gallikos Asklepias as a ransom ( $\lambda$ ú @ov) for Diogenes."23 On the basis of these inscriptions, she argues that "the term $\lambda$ ú @ov ('ransom')

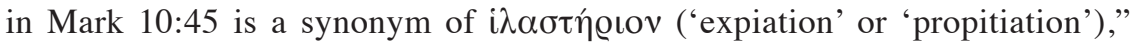
concluding, therefore, that "Jesus' death is interpreted here as a metaphorical ritual act of expiation for the offenses of many." 24 This inscriptional evidence provides an important background for understanding the meaning of $\lambda$ ú $\varrho o v$ in the GrecoRoman world. But, while cultic traditions and language may be in the background,

\footnotetext{
${ }^{18}$ On volume as a test case for determining both whether an author intended to allude to a passage and whether informed readers would catch the allusion, see Richard B. Hays, Echoes of Scripture in the Letters of Paul (New Haven: Yale University Press, 1989) 30.

${ }^{19}$ See the criticisms of Dieter Vieweger and Annette Böckler, “ 'Ich gebe Ägypten als Lösegeld für dich': Mk 10,45 und die jüdische Tradition zu Jes 43,3b-4,” ZAW 108 (1996) 594-607. Admittedly, LXX translators elsewhere (e.g., Exod 21:30; 30:12; Num 35:31-32) translate the noun כפר as $\lambda$ ú @ov.

${ }^{20}$ Adela Yarbro Collins, "The Signification of Mark 10:45 among Gentile Christians," HTR 90 (1997) 371-82; eadem, Mark: A Commentary (Hermeneia; Minneapolis: Fortress, 2007) 500; and eadem, "Mark's Interpretation of the Death of Jesus," JBL 128 (2009) 545-54.

${ }^{21}$ Yarbro Collins, "Signification of Mark 10:45," 372.

${ }^{22}$ Yarbro Collins, "Mark's Interpretation," 548.

${ }^{23}$ Yarbro Collins, Mark, 502.

${ }^{24}$ Yarbro Collins, "Mark's Interpretation," 549.
} 
the foreground of Mark 10:45 focuses on Jesus's contrast between the rulership of the Son of Man and the rulership of gentile leaders. Consequently, the cultic significance of $\lambda u ́ \tau \varrho o v$ language needs to be connected explicitly to this broader narrative discussion of rulership and servanthood in Mark 10.

In fact, the title "Son of Man" derives from Dan 7:13-14, which envisages the Son of Man coming with the clouds and being given dominion, glory, and kingship so that all people should serve him..$^{25}$ This title, then, has clear kingly connotations, and therefore supports my contention that the ransom saying needs to be situated within rulership discourses. ${ }^{26}$ Confirmation that Mark has Dan 7:13-14 in mind in Mark 10:35-45 might be found not only in the use of the title "Son of Man," but also in the shared terminology of authority (Dan 7:14: ‘' $\xi o v \sigma i ́ \alpha$; Mark 10:42:

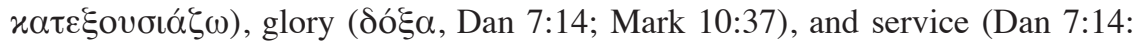

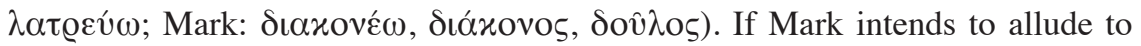
Dan 7 here, though, he reverses Danielic expectations: Mark's Jesus "says that the Son of Man came to serve rather than to be served, which is the opposite of the impression that one gets from Daniel 7." 27 The Son of Man does not require the service of others; rather, he offers his own service. Consequently, Mark redefines or clarifies what role the Danielic Son of Man plays in human history and does so by contrasting the Son of Man to gentile rulers.

In this regard, David Seeley also argues that the narrative foreground should guide readers in interpreting the ransom saying. Stressing the importance of Jesus's words about gentile rulers in 10:42 for the interpretation of 10:43-45, he locates the passage within the context of "Hellenistic and classical ideas concerning the true ruler." 28 Seeley discusses texts, ranging from Plato to Dio Chrysostom, that portray the ruler working for the good of his subjects, only two of which contain

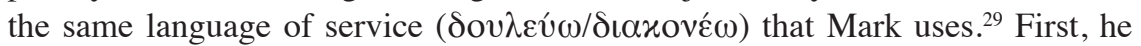
cites Plato, who states: "Now it is necessary that every man should hold, regarding

${ }^{25}$ See the more explicit citations of Dan 7:13-14 in Mark 13:26 and 14:62, as well as Dale C. Allison Jr., Constructing Jesus: Memory, Imagination, and History (Grand Rapids: Baker Academic, 2010) 293-303.

${ }^{26}$ See William Horbury, "The Messianic Association of 'The Son of Man," JTS 36 (1985) 34-55, and James C. VanderKam, "Righteous One, Messiah, Chosen One, and Son of Man," in The Messiah: Developments in Earliest Judaism and Christianity (ed. James H. Charlesworth; Minneapolis: Fortress, 1992) 169-91.

${ }^{27}$ Marcus, Mark 8-16, 749.

${ }^{28}$ David Seeley, "Rulership and Service in Mark 10:41-45," NovT 35 (1993) 234-50, at 234. See also Dowd and Struthers Malbon, "Significance of Jesus' Death," and Winn, "Tyrant or Servant?"

${ }^{29}$ On kingship discourses in Hellenistic Judaism, see Oswyn Murray, "Aristeas and Ptolemaic Kingship," JTS 18 (1967) 337-71; Doron Mendels, Identity, Religion, and Historiography: Studies in Hellenistic History (JSPSup 24; Sheffield: Sheffield Academic Press, 1998) 325-33; Oda Wischmeyer, "Herrschen als Dienen-Mk 10,41-45," ZNW 90 (1999) 28-44; and C. D. Elledge, The Statutes of the King: The Temple Scroll's Legislation on Kingship (11Q19 LVI 12-LIX 21) (CahRB 56; Paris: Gabalda, 2004). This ideal is not confined to Hellenistic sources. For the king as servant in Jewish scriptures, see $1 \mathrm{Kgs}$ 12:7 LXX and the discussion of Moshe Weinfeld, "The King as the Servant of the People: The Source of the Idea," JJS 33 (1982) 189-94. 


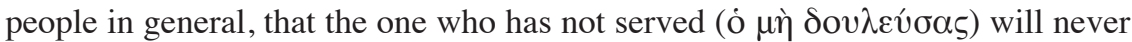
become a praiseworthy master ( $\left.\left.\varepsilon \varepsilon \sigma \pi \tau_{\tau}\right\rceil\right)$, and that the right way to gain honor is to serve well rather than to rule well" (Leg. 762E) ${ }^{30}$ Similarly, Dio Chrysostom avers that the sun is perhaps the finest illustration of kingship in that it "endures a

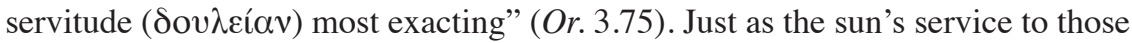
under it in no way diminishes its splendor, so too the good king demonstrates his glory through service to those underneath him. Seeley argues that this idea of rulers serving their subjects is common within broader Greco-Roman political theory: "The Greek and Hellenistic world had a long tradition of painting the ruler in the colors of servitude." ${ }^{31}$

Given the fact that Mark places the ransom saying within a discussion of gentile rulers, Seeley is right to situate Mark 10:45 within Hellenistic kingship discourses. But, as he acknowledges, his treatment of these discourses fails to connect them to Jesus's claim that the Son of Man gives his life as a $\lambda$ ú @oov for the many. Further, he argues that the ransom saying "veers from a martyrological, exemplary approach to service (which was probably influenced by Cynic traditions), and turns instead in a substitutionary direction." 32 Consequently, Seeley concludes that Mark is indebted not to Hellenistic rulership discourses at this point, but to the influence of the apostle Paul, who taught that Christ's death served as a ransom (Rom 3:24; $8: 23 ; 1$ Cor $1: 30)$. Yet there is no reason why Mark could not hold both exemplary and substitutionary understandings of Christ's death. Paul's writings, for instance, give evidence of both a substitutionary understanding, as his use of redemption language suggests, and an exemplary understanding (e.g., Phil 2:5-8; 1 Cor 11:1; 1 Thess 1:6) of Jesus's death. As the work of Joel Marcus suggests, Seeley may well be correct to argue that Mark knew Paul's views, but his recourse to Paul's writings to explain Mark's use of $\lambda u ́ \tau \varrho o v$ at this point in the narrative is unsatisfying. ${ }^{33}$ If one were able to demonstrate a connection between rulership discourses and ransom language, there would be no reason to posit Paul's somewhat intrusive influence at this point. In the remainder of this article, I will discuss evidence of the "missing link" between rulership discourses and Mark 10:45.

\footnotetext{
${ }^{30}$ Unless otherwise noted, non-Jewish Greco-Roman sources are quoted from the Loeb Classical Library.

${ }^{31}$ Seeley, "Rulership," 238. See also Hans Volkmann, ENDOXOS DULEIA: Kleine Schriften zur alten Geschichte (Berlin: de Gruyter, 1975) 74-81; John N. Collins, Diakonia: Re-interpreting the Ancient Sources (Oxford: Oxford University Press, 1990); and Dale B. Martin, Slavery as Salvation: The Metaphor of Slavery in Pauline Christianity (New Haven: Yale University Press, 1990) 42-49. Martin contrasts what he terms the "populist model" of leadership, in which the ruler serves the common people, to the "benevolent patriarchal model," in which the ruler governs benevolently, yet superiorly (Slavery as Salvation, 86-116).

${ }^{32}$ Seeley, "Rulership," 249.

${ }^{33}$ Ibid., 249. Early Christians picked up on this similarity between Paul and Mark, as noted by Yarbro Collins, Mark, 500 n. 116, and Christopher J. Edwards, "Pre-Nicene Receptions of Mark 10:45/Matt 20:28 and Phil 2:6-8," JTS 61 (2010) 194-99. For Mark's essentially Pauline perspective, see Joel Marcus, "Mark - Interpreter of Paul," NTS 46 (2000) 473-87.
} 


\section{The Self-Sacrifice of Rulers}

Despite her own cultic interpretation, Yarbro Collins notes (acknowledging her dependence on Dieter Georgi) that Mark 10:45 "is strikingly similar" to a saying that Dio Cassius claims the Roman Emperor Otho (January-April 69 CE) made to his supporters during his civil war with Vitellius: "I shall free myself [i.e., commit suicide], that all people may learn from this that you chose for your emperor one

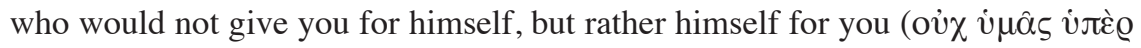

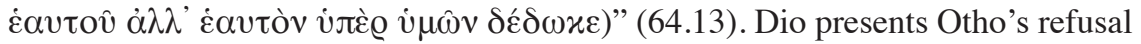
to continue to wage war against Vitellius in order to maintain his reign as a rather surprising move-after all, it is not often that emperors give thought to the lives that are lost in order to maintain their own power. Otho gives ( $\delta \varepsilon \dot{\delta} \delta x \varepsilon$ ) his life

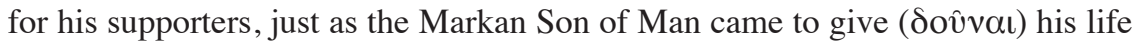
for the many.

Dating to the late second century or early third century CE, Dio Cassius's comments are, admittedly, rather late when considering the Gospel of Mark. Already in the late first century CE, though, Plutarch also presents Otho's supporters begging him not to surrender, asking him to use their souls and bodies for himself

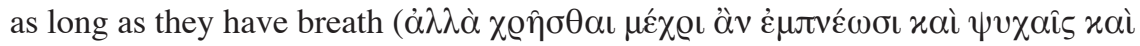

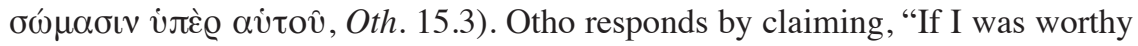

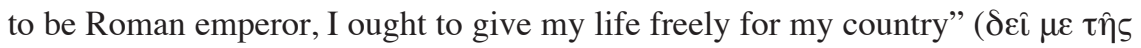

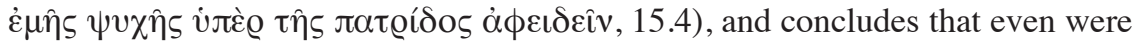
he to be victorious, it would not be worth as much as giving himself for peace

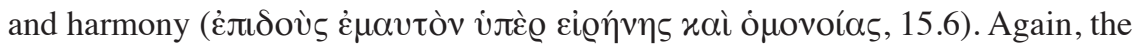

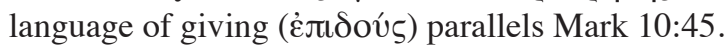

Nonetheless, what keeps Yarbro Collins from connecting this episode to Mark $10: 45$ is the fact that these accounts lack the key word $\lambda$ ú $\varrho o v .{ }^{34}$ In partial response to this hesitancy, one might point to the evidence of Plutarch's contemporary, Tacitus, who likewise portrays Otho's suicide. In Tacitus's account, Otho protests the continuation of battle in the following words: "To expose such courageous and brave men as you to further dangers . . . I consider too great a price (pretium) for my life" (Ann. 2.46; cf. Martial Epigr. 6.32; Suetonius Oth. 10.1-2). Thus, according to Tacitus, Otho portrays the hypothetical deaths of others serving as the price paid to preserve his own life. Such deaths would function as a ransom for his own life. These historians present Otho not only refusing to sacrifice others for his own reign, but also committing suicide in order to prevent further war on his behalf. The loss of his one life preserves the lives of untold others. This exchange of the one life of the ruler for the many lives of his subjects, therefore, provides an illuminating parallel to Jesus's words in Mark 10:45.

${ }^{34}$ Yarbro Collins, "Signification of Mark 10:45," 371. 
Further, we find ransom language used of the self-sacrifice of rulers in a number of other sources. For instance, in the fourth century BCE, Euripides depicts Creon, the ruler of Thebes, forced to decide between saving his son Menoeceus and saving his city by sacrificing his son to placate Ares. He states:

What can one say? Yet what I must say is clear. Never shall I go so far in wretchedness as to offer my child to the city for slaughter! All men alive love their children, and no one would give his own child to be killed. I do not want the praise of someone who kills my children! I myself am ready to

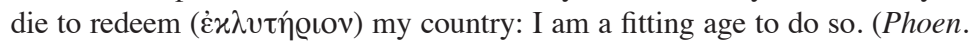
963-969; LCL slightly modified)

Creon expresses his desire that he, an old man, might die in place of the young: his death would redeem both his city and, in effect, his son. Instead, Menoeceus offers himself to save the city.

Likewise, the poet Lucan, a contemporary of Mark, portrays the Roman senator Cato wishing that he could offer his own life on behalf of his fellow citizens. Addressing Brutus, Cato claims:

Let Rome pay atonement (piaculum) in full to the pitiless gods, and let no man's life be denied to the claim of war! But would it were possible for me, condemned by the powers of heaven and hell, to be the scapegoat for the nation! As hordes of foemen bore down Decius when he had offered (devotum) his life, so may both armies pierce this body, may the savages from the Rhine aim their weapons at me; may I be transfixed by every spear, and may I stand between and intercept every blow dealt in this war! Let my blood redeem the nations (Hic redimat sanguis populos), and my death pay the whole penalty incurred by the corruption of Rome (Quidquid Romani meruerunt pendere mores). (Bell. civ. 2.304-313; LCL slightly modified)

Cato portrays his own willingness to die as an imitation of the actions of the gens Decia, which was renowned for its willingness to die for Rome. Although lacking explicit ransom language, Livy portrays both the Roman consul Publius Decius and his son Decius, also a Roman consul, giving their lives to expiate the anger of the gods (piaculum omnis deorum irae, 8.9.10) in order to preserve fourth-century BCE Rome. As the younger Decius boasts, "It is the privilege of our family that we should be sacrificed (piacula) to avert the nation's perils" (10.28.13; cf. Cicero Fin. 2.61). ${ }^{35}$ Inspired by these sacrificial deaths, Cato wishes that his own death might serve as a ransom to deliver Rome from the divine punishment for the nation's evil actions. Of Cato, Lucan avers: "Such was the character, such the inflexible rule of austere Cato - to observe moderation and hold fast to the limit, to follow nature, to give his life for his country (patriaeque inpendere vitam), to believe

${ }^{35}$ See Ludwig Deubner, "Die Devotion der Decier," Archiv für Religionsgeschichte 8 (1905) 66-81; H. S. Versnal, "Two Types of Roman devotio," Mnemosyne 29 (1976) 365-410; and L. F. Janssen, "Some Unexplored Aspects of devotio Deciana," Mnemosyne 34 (1981) 357-81. 
that he was born to serve (servare) the whole world and not himself" (2.380-383). Consequently, Lucan's portrayal of Cato connects the cultic sense (note the use of piaculum in line 304) of ransom language (redimere) highlighted by Yarbro Collins to a ruler's desire to protect and serve his nation.

This evidence demonstrates the willingness, at times hypothetical and at times real, upon the part of rulers to offer their lives in place of their subjects. Such examples appear in both Greek and Roman literature, showing that, despite the disparate historical contexts within which these authors write and despite the different political systems and theories which these authors espoused, the ideal of the self-sacrificing ruler was widespread in the Greco-Roman world. This ideal was especially prominent in the Roman imperial period where, as Adam Winn notes, the ruler needed to tread lightly in order not to offend the Roman "commitment to self-rule" and "rejection of monarchial tyranny." 36 Mark 10:45 fits within this depiction of true rulership.

\section{Seneca's De clementia and Mark 10:45}

It is perhaps surprising, therefore, that we find such a stark contrast to this larger discourse in the political philosophy of Seneca's De clementia, which contains a number of remarkable, and previously unnoted, parallels to Mark 10:42-45, including its $\lambda u ́ \tau \varrho o v$ language. Seneca composed De clementia in 55 or $56 \mathrm{CE}$, shortly after the young Nero became emperor. ${ }^{37}$ As Susanna Braund demonstrates, the work is "a complex hybrid between different models: didactic kingship treatise addressed to a new ruler, panegyrical oration, and philosophical disquisition on one of the classic virtues of a ruler." ${ }^{38}$ In it, Seneca likely had his eye on a number of different audiences, including both Nero and the ruling elite. Although he explicitly addresses Nero alone, Braund notes the way in which the work functions as "a justification of imperial rule to the elite of Rome, Italy, and the provinces." ${ }^{39}$ Further, Robert A. Kaster has argued that from the beginning Seneca worked to distinguish Nero from his predecessor, Claudius, whom he lampooned quite mercilessly in

\footnotetext{
${ }^{36}$ Winn, “Tyrant or Servant?” 330. Citing the evidence of Suetonius Cal. 23-26, 38; Nero 32-35, Winn argues that, while most emperors presented "themselves as citizens who were subjects to Roman law," Caligula and Nero "presented themselves as supra leges" ("Tyrant or Servant?" 337).

${ }^{37}$ This date is based upon Seneca's reference to the actions of the young Augustus when he "was the same age that you [i.e., Nero] now are, just past his eighteenth birthday" (Clem. 1.9.1). On the issue of dating, see the full discussions of Otto Zwierlein, "Zur Datierung von Senecas De Clementia," Rheinisches Museum für Philologie 139 (1996) 14-32, and Ermanno Malaspina, L. Annaei Senecae: De clementia libri duo (Alexandria: Edizioni dell'Orso, 2002) 292-98. Unless otherwise stated, all translations of De clementia come from Susanna Braund, Seneca: "De Clementia" (Oxford: Oxford University Press, 2009).

${ }^{38}$ Braund, Seneca, 1.

39 Ibid., 23.
} 
Apocolocyntosis. He concludes, "On Clemency obviously participates in this attempt to 'brand' Nero as quite a different sort of emperor." ${ }^{40}$ De clementia, then, does not merely instruct Nero; it also presents him as an alternative to previous types of rulers.

Throughout, Seneca stresses the importance of the ruler's cultivation of the virtue of clemency in dealing with his subjects. ${ }^{41}$ In the midst of this treatise, though, he digresses in order to discuss the relationship between the emperor and the empire, arguing that the emperor is to the masses as the mind is to the body. He concludes, "The body is entirely at the service of the mind. And although the body is so much larger and more impressive while the mind remains hidden and insubstantial with its precise hiding-place unknown, all the same, the hands and feet and eyes do its business and this skin we see is its protection" (1.3.5). Likewise, Seneca declares, the ruler "is the link that holds the state together. He is the breath of life to all these many thousands who on their own would only be a heavy weight and easy prey if that mind of the empire were withdrawn" (ille est enim uinculum per quod res publica cohaeret, ille spiritus uitalis quem haec tot milia trahunt nihil ipsa per se futura nisi et praeda, si mens illa imperii subtrahatur, 1.4.1). Just prior to this statement, Seneca claims:

[The masses are] totally ready to throw themselves on the swordpoints of assassins in his defence and to lay their bodies on the ground if his path to safety has to be made with human slaughter. They protect his sleep with nightly watches. They defend his flanks with a surrounding barrier. At incursions of danger, they put themselves in its path. This unanimity among peoples and cities about offering protection and love to their kings and about hurling themselves and all they have wherever the safety of their ruler requires is not without reason. And it is not lack of self-worth or of sanity when many thousands face the sword for one individual and when with many deaths they ransom one life of sometimes a feeble old man (nec haec uilitas sui est aut dementia pro uno capite tot milia excipere ferrum ac multis mortibus unam animam redimere nonnumquam senis et inualidi). (1.3.3-4, Braund, slightly modified)

${ }^{40}$ Robert A. Kaster, "On Clemency," in Seneca: Anger, Mercy, Revenge (ed. Robert A. Kaster and Martha C. Nussbaum; Chicago: University of Chicago Press, 2010) 133-94, at 133.

${ }^{41}$ On Roman views of clemency, see Ernst Bux, "Clementia Romana: Ihr Wesen und ihre Bedeutung für die Politik des römischen Reiches," Würzburger Jahrbücher für die Altertumswissenschaft 3 (1948) 201-31; Traute Adam, Clementia Principis: Der Einfluß hellenistischer Fürstenspiegel auf den Versuch einer rechtlichen Fundierung des Principats durch Seneca (Kieler Historische Studien 11; Stuttgart: Ernst Klett, 1970); Miriam T. Griffin, "Clementia after Caesar: From Politics to Philosophy," in Caesar Against Liberty: Perspectives on His Autocracy (ed. Francis Cairns and Elaine Fantham; Papers of the Langford Latin Seminar 11; Cambridge, UK: Francis Cairns, 2003) 157-82; David Konstan, "Clemency as a Virtue," CP 100 (2005) 337-46; and Melissa Barden Dowling, Clemency and Cruelty in the Roman World (Ann Arbor: University of Michigan Press, 2006). 
If the ruler is the mind and the state the body, it is no wonder that the many are willing to die for the one: "So it is their own safety that people love when for one individual they lead forth legions ten at a time into action, when they race forwards into the front line and expose their chests to wounds to prevent their commander's standard being defeated" (1.4.1). This willingness to sacrifice many lives for the emperor illustrates Seneca's claim that "the body is entirely at the service of the mind" (quemadmodum totum corpus animo deseruit, 1.3.5). Although this discussion appears to stray from Seneca's actual intention, he notes its importance for his claim that Nero should show clemency: "The fact is that if - as the argument so far suggests - you are the mind of the state and the state is your body (tu animus rei publicae [tuae] es, illa corpus tuum), you see, I think, how essential clemency is: you are showing mercy to yourself when you seem to be showing it to someone else" (1.5.1; see also 2.2.1). Thus, while Seneca's larger rhetorical strategy conforms to the broader discourse of the ruler serving the ruled, his digression reveals an underlying tension within it.

Mark 10:42-45 contains a number of commonalities with this apparent digression in De clementia. Most significantly, Seneca counsels Nero to be unbothered by the fact that many die on his behalf. It is fitting that "many deaths ransom/redeem one life" (ac multis mortibus unam animam redimere), namely, the life of the emperor. As Braund states, "The immeasurability of the masses contrasts sharply with the singleness of the ruler's life." ${ }^{42}$ Seneca portrays the hypothetical deaths of many people redeeming Nero's one life, whereas Mark's Jesus portrays his one death functioning to redeem the lives of many. ${ }^{43}$ The parallels at the verbal level strengthen the correspondence of these two statements at the conceptual level. Although writing in Latin, Seneca's wording is remarkably similar to Mark's phrase

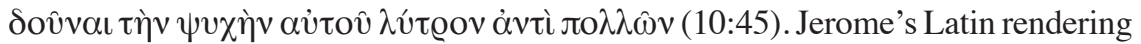
of Mark 10:45b (daret animam suam redemptionem pro multis) confirms that the

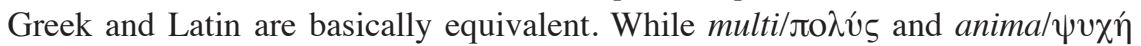
are common to both passages, these words occur frequently. The collocation of

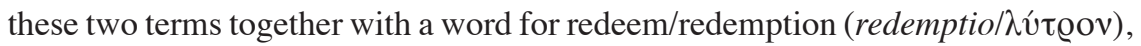
however, is striking.

Additionally, Seneca argues that just as the entire body serves the mind (quemadmodum totum corpus animo deseruit, 1.3.5), so, too, do the many or the masses serve the ruler. Braund states, "the -seru-root here suggests that the nature of the relationship between body and mind, masses and ruler, is that of service or

${ }^{42}$ Braund, Seneca, 210. See Malaspina, L. Annaei Senecae, 262.

${ }^{43}$ To be fair, Seneca can elsewhere say that God gave Caligula's father Germanicus and his grandfather Tiberius the authority to rule because, "instead of sacrificing the state to themselves, they have sacrificed themselves to the state" (Ben.4.32.2). Nonetheless, this statement fits with his argument in De clementia that what the emperor does to the state he does to himself. For that matter, as Winn points out, "Clearly, Seneca is speaking figuratively here, referring to the emperor sacrificing his own power, glory and wealth for the good of the Roman state” (“Tyrant or Servant?" 346). 
slavery." ${ }^{44}$ Likewise, Seneca refers to the mind as a master (dominus) over the body parts (1.3.5). Although he uses neither of these terms explicitly with reference to the ruler and the masses, the implication seems clear: the masses serve (deseruit) the one master (dominus) ${ }^{45}$ This sentiment accords with Jesus's claim that gentile

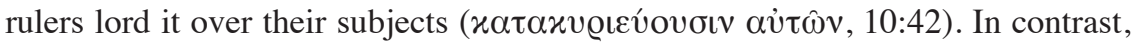
Mark's Jesus states that "the Son of Man did not come to be served, but to serve"

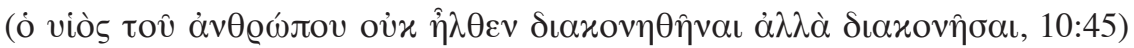

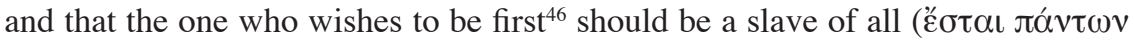

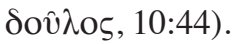

In contrast to Seneca, then, who argues that it is fitting for many people to die in order to ransom the one king/ruler, Mark's Jesus states the opposite: it is proper that the Son of Man die as a ransom for the many. The Son of Man rules in order to serve the many, rather than having the many serve him. These verbal similarities between Mark 10:42-45 and Seneca's De clementia provide a previously unappreciated parallel to Mark's ransom language. Admittedly, we cannot know how familiar the wider Roman society was with Seneca's argument in De clementia, ${ }^{47}$ nor can we know whether Mark and his community knew of it. ${ }^{48}$ Nonetheless, Miriam T. Griffin argues, "since it is obvious that reassurance of the public was a large part of Seneca's aim, we must assume that the view of the Principate set out in De Clementia was basically acceptable to the reading public." ${ }^{49}$ If Seneca hoped to provide a positive account of Nero's rulership, the way in which he portrays rulers and ruled must have been both commonly known and well received. ${ }^{50}$

${ }^{44}$ Braund, Seneca, 207. See also Cicero Leg. 1.39.

${ }^{45}$ As Braund (Seneca, 208) notes, "By reserving the language of domination and slavery for the comparison [between body and mind/soul], Seneca keeps at arm's length the implication that the Roman people are Nero's slaves."

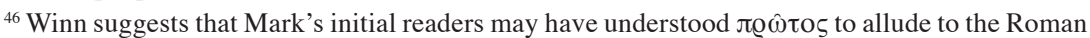
emperor's claim to be princeps - the "first citizen" ("Tyrant or Servant?" 344-45).

${ }^{47}$ The only evidence of its influence in the Roman period is its use in the late-first century play Octavia, which was erroneously attributed to Seneca. See the evidence of Gesine Manuwald, "Der 'Fürstenspiegel' in Senecas De clementia und in der Octavia,' MH 59 (2002) 107-27.

${ }^{48}$ It is possible that both Mark and his readers knew De clementia, if Mark and his community knew Latin, as argued by Bas M. F. Van Iersel, Mark: A Reader-Response Commentary (JSNTSup 164; Sheffield: Sheffield Academic Press, 1998) 34-35, and Incigneri, Gospel to the Romans, 100-103.

${ }^{49}$ Miriam T. Griffin, Seneca: A Philosopher in Politics (Oxford: Clarendon, 1976) 141.

${ }^{50}$ As Braund observes, De clementia "is the closest thing we have to a 'kingship treatise' in Latin literature from any period." In part, this is because of Roman aversion to kings (Seneca, 19). See Andrew Wallace-Hadrill, “Civilis Princeps: Between Citizen and King," JRS 72 (1982) 32-48. On kingship treatises, see the seminal article of Erwin R. Goodenough, "The Political Philosophy of Hellenistic Kingship," YCS 1 (1928) 55-102, as well as Helen S. Lund, Lysimachus: A Study in Early Hellenistic Kingship (London: Routledge, 1992); A. E. Samuel, "The Ptolemies and the Ideology of Kingship," in Hellenistic History and Culture (ed. Peter Green; HCS 9; Berkeley: University of California Press, 1993) 168-210; Erich S. Gruen, "Seleucid Royal Ideology," SBL 
Indeed, similar sentiments are found in other writers. For instance, the seventhcentury BCE Spartan poet Tyrtaeus claims "it is noble for a good man to die, falling in the forefront of battle, fighting for his fatherland." ${ }^{51}$ The first-century BCE Roman poet Horace holds similar sentiments: "It is sweet and fitting to die for one's country" (Carm. 3.2.13). ${ }^{52}$ More closely related to Seneca's remarks, Isocrates (ca. 436-338 BCE), in his Letter to Philip, the king of Macedonia, asserts:

Consider no blessing more important than your safety, in order that you may not only duly make use of the victories which may be yours but also may rectify the mischances that may befall you. You might observe that the Lacedaemonians also are extremely solicitous for the safety of their kings, and appoint the most distinguished of the citizens as their bodyguards, and that for them it is a greater disgrace to suffer the kings to meet death than to throw away their shields. $(1.6)^{53}$

Isocrates here chastises Philip for his previous behavior in military engagements that endangered his life and therefore the welfare of his subjects. Likewise, Aristotle, in distinguishing between a tyrant and a king, avers: "Kings are guarded by the citizens in arms, whereas tyrants have foreign guards, for kings rule in accordance with law and over willing subjects, but tyrants rule over unwilling subjects, owing to which kings take their guards from among the citizens but tyrants have them to guard against the citizens" (Pol. 3.9.4; cf. 5.8.7). For Aristotle, citizens are willing to guard kings because they know that kings, unlike tyrants, are solicitous of their wellbeing. These writers attest a common tradition that held that it was noble to die for one's country or one's ruler.

More broadly, numerous Greek and Roman writers use the same body analogy that Seneca employs to portray and justify the relationship between rulers and their subjects. Plato, for instance, argues:

Seminar Papers, 1999 (SBLSP 38; Atlanta: Scholars Press, 1999) 24-53; and David E. Hahm, "Kings and Constitutions: Hellenistic Theories," in The Cambridge History of Greek and Roman Political Thought (ed. Christopher Rowe and Malcolm Schofield; Cambridge, UK: Cambridge University Press, 2006) 457-76.

${ }^{51}$ Taken from Michael Gagarin and Paul Woodruff, eds., Early Greek Political Thought from Homer to the Sophists (Cambridge Texts in the History of Political Thought; Cambridge, UK: Cambridge University Press, 1995) 24.

${ }^{52}$ As scholars frequently note, Mark 10:45 also finds a parallel in 4 Maccabees's portrayal of Eleazar, who died for his faithfulness to the Jewish law. According to 4 Maccabees, at the point of death, Eleazar called out to God, saying: "Make my blood a purification for them, and take my life

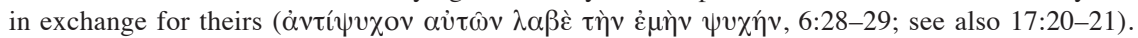
Although 4 Maccabees lacks the precise ransom language that Mark uses, it nonetheless contains a similar idea: the life of one person can buy the lives of many others. See Sam K. Williams, Jesus' Death as Saving Event: The Background and Origin of a Concept (HDR 2; Missoula, MT: Scholars Press, 1975) 165-202, and Jan Willem van Henten, The Maccabean Martyrs as Saviours of the Jewish People: A Study of 2 and 4 Maccabees (JSJSup 57; Leiden: Brill, 1997) 153.

${ }^{53}$ See Isocrates, De pace 143: "those Spartans who are not ready to lay down their lives for their kings in battle are held in greater dishonour than men who desert their post and throw away their shields." 
When the soul and the body are joined together, nature directs the one to

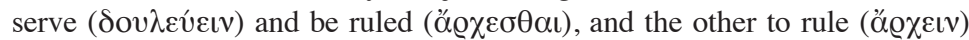

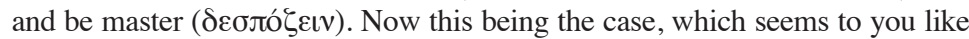
the divine, and which like the mortal? Or do you not think that the divine is by nature fitted to rule and lead, and the mortal to obey and serve. (Phaed. 80A; cf. Leg. 10.896C; 12.959A-B; Tim. 44D)

Similarly, Aristotle defends his claim that citizens will willingly guard (and die for) their rulers on the basis of this body-soul analogy: "Inasmuch therefore as one would count the soul of an animal to be more a part of it than the body, so also the factors in states corresponding to the soul must be deemed to be parts of them more than those factors which contribute to necessary utility" (Pol. 4.3.13). Aristotle proceeds to identify the soul with the military, judicial, and political elites. Since these classes are indispensible to the proper running of the state, those classes that are nonessential should gladly offer their lives to preserve them. ${ }^{54}$ The first-century BCE Roman historian and politician Sallust makes a similar point, stating of the body and soul, "All our power, in contrast, is situated in both the mind and body; we use the mind to rule, the body rather to serve" (Sed nostra omnis vis in animo et corpore sita est; animi imperio, corporis servitio magis utimur, Bell. Cat. 1.2). Writing shortly after Sallust, Dionysius of Halicarnassus reiterates this belief, but connects it explicitly to rulers and ruled: "For the ignorant multitude will always require and never stop requiring intelligent leadership, while the senate, which is

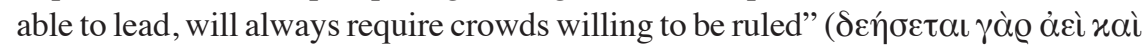

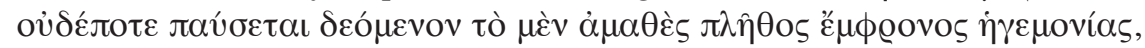

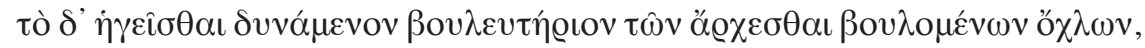
Ant.Rom. 6.85.1). As Michelle V. Lee concludes,

Probably the most enduring "source" [of body language] is the political/ philosophical image of the cosmos or state as a body. The image was widespread in antiquity, with its best-known form that of the Menenius Agrippa fable, in which Agrippa persuaded the plebeians to cease their rebellion against the senate by arguing that since the state, like a body, is made up of a number of diverse parts, all of the parts perform a necessary function, including the senators, for the good of the whole..$^{55}$

${ }^{54}$ Philo makes a similar claim in Virt. 186: "In a ship the pilot is worth as much as all the crew, and in an army the general as much as all the soldiers, since if he fall, defeat results as certainly as it would if the whole force were annihilated."

${ }^{55}$ Michelle V. Lee, Paul, the Stoics, and the Body of Christ (SNTSMS 137; Cambridge, UK: Cambridge University Press, 2006) 9. See also, Jean Béranger, Recherches sur l'Aspect Idéologique du Principat (Schweizerische Beiträge zur Altertumswissenschaft 6; Basel: Reinhardt, 1953) 218-52; Dietmar Kienast, “Corpus Imperii: Überlegungen zum Reichsgedanken der Römer," in Romanitas-Christianitas: Untersuchungen zur Geschichte und Literatur der römischen Kaiserzeit: Johannes Straub zum 70. Geburtstag am 18. Oktober 1982 gewidmet (ed. Gerhard Wirth; Berlin: de Gruyter, 1982) 1-17; and John K. McVay, "The Human Body as Social and Political Metaphor 
It appears, then, that De clementia provides us with an account of rulership that was widely disseminated in the Greco-Roman period in the hopes of justifying and supporting the emperor. ${ }^{56} \mathrm{~A}$ hierarchy akin to that of mind to body existing between the emperor and his subjects implies that the various body parts not only serve the mind, but also rightly sacrifice themselves on the mind's behalf. After all, the mind's existence is essential; body parts are (relatively) expendable.

Such examples, although lacking ransom language, demonstrate that Seneca's De clementia was not alone in advocating such political ideology. This discourse was, in the words of James C. Scott, part of "the dominant transcript" of ruler discourses in the first century CE.${ }^{57}$ People were no doubt accustomed to the political theory that recommended that subjects die for their rulers. By accessing the public transcript of Greco-Roman rulership discourses, Mark's Jesus calls into question the behavior of gentile rulers. Part of the public transcript, as seen above, depicted the king ruling on behalf of his subjects. He was their servant. This portrayal was a necessary part of the public transcript, since the king needed to justify his power and privilege. As Scott argues, rulers propagated a self-portrait of how they desired to be viewed. Of this public transcript, he says:

If, however, this flattering self-portrait is to have any rhetorical force among subordinates, it necessarily involves some concessions to their presumed interests. That is, rulers who aspire to hegemony in the Gramscian sense of that term must make out an ideological case that they rule, to some degree, on behalf of their subjects. This claim, in turn, is always highly tendentious but seldom completely without resonance among subordinates. ${ }^{58}$

In spite of the fact that this portrait was flattering, or rather, precisely because it was self-flattering, it could also become a problem for rulers. As Scott recognizes, a self-flattering portrait within the public transcript "is not without its political costs since such disguises can become a political resource for subordinates. Ruling groups can be called upon . . . to live up to their own idealized presentation of themselves to their subordinates." ${ }^{59}$ The criticism of gentile rulers in Mark 10:42-45

in Stoic Literature and Early Christian Writers," BASP 37 (2000) 135-47. For primary evidence, see, for instance, Dionysius of Halicarnassus Ant. Rom. 6.83.2; Livy 2.32.8-12, Philo Praem. 114; Seneca Ep. 114.23-24; Curtius Rufus Historiae Alexandri 10.9.1; Dio Chrysostom Or. 3.68-69; Plutarch Galb. 4.3; and Tacitus Ann. 1.12.

${ }^{56}$ On the broad dissemination of Roman propaganda about emperors both in writing and in material culture, see M. P. Charlesworth, "The Virtues of a Roman Emperor: Propaganda and the Creation of Belief," Proceedings of the British Academy 23 (1937) 105-35; J. R. Fears, "The Cult of Virtues and Roman Imperial Ideology," ANRW 2.17.2 (1981) 827-948; and Carlos F. Noreña, "The Communication of the Emperor's Virtues," JRS 91 (2001) 146-68.

${ }^{57}$ Scott, Domination and the Arts of Resistance: Hidden Transcripts (New Haven: Yale University Press, 1990). See Adam, Clementia Principis.

${ }^{58}$ Scott, Domination, 18.

${ }^{59}$ Ibid., 54. 
occurs through its appeal to the public transcript.$^{60}$ Mark's Jesus accesses the public transcript of Greco-Roman kingship discourses in order both to call into question the type of authority these rulers exercise and to contrast them with his own rule, which truly fulfills this flattering portrait of the servant king. ${ }^{61}$ While those who rule the gentiles claim to serve them, they in fact rule and exercise authority over them in a way that contrasts with the rulership of the Son of Man, who came in order to die for the many.

\section{Jesus's Narratival Embodiment of Mark 10:45}

Not only does Seneca's De clementia demonstrate a plausible connection between Mark's ransom language and Jesus's earlier remarks about the way in which gentile rulers exercise their authority (10:42), ${ }^{62}$ it also illuminates Jesus's subsequent behavior. Immediately after criticizing gentile rulers, Mark portrays a blind man twice addressing Jesus as "son of David" (10:46-52). As Frank Matera insists, "Inasmuch as Bartimaeus has just called Jesus the Son of David (10:47-48), the implication by association is that Jesus comes as the Son of David and accompanying his arrival is the coming Kingdom of David."63 The people surrounding Jesus attempt to silence this inconsequential man's entreaties for mercy ('่̇ $̇$ ¡oóv $\mu \varepsilon$ ), but Jesus hears the man's cries and restores his sight, thereby confirming his claim that he is a king who serves his subjects. If Mark identifies

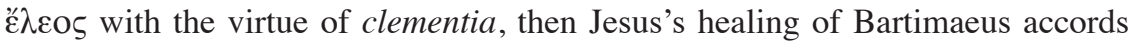
with Seneca's admonition toward clemency. He would then be portraying Jesus's healing ministry as Jesus's embodiment of the Roman virtue of clemency. If so,

${ }^{60}$ Which specific rulers Mark has in mind, if any, is difficult to answer. Within the narrative, surely Herod (who was Idumean after all) stands out, since he puts John the Baptist to death in order to fulfill his rash oath (Mark 6). Since we are uncertain about when Mark wrote his gospel, we can only speculate about external referents. Nonetheless, readers would likely have thought of the Roman emperor first and foremost.

${ }^{61} \mathrm{I}$ am grateful to one of the anonymous reviewers for drawing my attention to the fact that Luke omits the ransom saying altogether. In light of my argument that we should understand the ransom saying within an imperial context, scholars might point to this omission as further evidence for a reading of an irenic Luke who, in the words of Luke Timothy Johnson, portrays the Jesus movement as a "philosophically enlightened, politically harmless, socially benevolent and philanthropic fellowship" (The Gospel of Luke [SP 3; Collegeville, MN.: Liturgical Press, 1991] 9). See also Hans Conzelmann, The Theology of St. Luke (trans. Geoffrey Buswell; New York: Harper, 1960) 86-87. Yet Luke does retain and rework the negative statements about gentile rulers found in Mark 10:42-45a: "The kings of the gentiles ruler over them, and those in authority over them are called benefactors. But you are not like this; rather, the greatest among you must be as the youngest, and the leader as the servant. For who is greater, the one who reclines at the table or the one who serves? Is it not the one reclining? But I am in your midst as one who serves" (Luke 22:25-27).

${ }^{62}$ Kenneth W. Clark argues that $x \alpha \tau \alpha x v \varrho \iota \varepsilon v ́ \omega$ should not be understood negatively, citing such

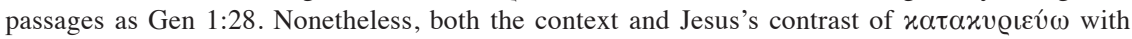
what is to occur among his disciples demonstrates that it has a negative connotation for Mark (The Gentile Bias and Other Essays [NovTSup 54; Leiden: Brill, 1980] 207-12).

${ }^{63}$ Frank J. Matera, The Kingship of Jesus: Composition and Theology in Mark 15 (SBLDS 66; Chico, CA: Scholars Press, 1982) 73. 
Mark agrees with Roman political theory on the centrality of this virtue for proper rulership, connecting it to Jesus, the son of David. Some scholars have pointed to Jesus's words in Mark 12:35-37, which seem to undermine efforts to identify Jesus with the Davidic Messiah. ${ }^{64}$ Nevertheless, as Joel Marcus acknowledges, earlier in the narrative "Jesus was hailed as 'the Son of David' by Bartimaeus (10:47-48) and as the restorer of 'the dominion of our father David' by the crowd at the triumphal entry (11:9-10), and in neither case did he reject the link with David." ${ }^{65}$ Elsewhere, Marcus suggests that Mark remains ambivalent about the title "son of David" because of the military connotations it took on especially during the Jewish revolt. ${ }^{66}$ We see this portrayal of a militant Davidic Messiah in Psalm of Solomon 17, which depicts David's seed ruling over ( $\beta \alpha \sigma \iota \lambda \varepsilon v 0 \alpha \iota)$ God's servant Israel (17.21) and vanquishing the gentiles (17.22-25). Bartimaeus's claim that Jesus is the son of David, coming as it does immediately after Jesus's claim that he came to serve and not to be served, helps to redefine the role of the son of David in terms of servanthood.

On the other hand, Seneca distinguishes carefully between clementia and misericordia, the latter of which is equivalent to the Greek word ' translation of Mark 10:47-48). ${ }^{67}$ Seneca states: "At this point it is relevant to ask what pity (misericordia) is. Most people, after all, praise it as a virtue and call a man who shows pity a good man. But this, too, is a defect of the mind. Both of the defects that we should avoid are close to strictness and to clemency . . . under the guise of clemency (clementia) we fall into pity (misericordia)," the latter of which is something that all good men, especially rulers, will avoid (2.5.1). Here it seems that Seneca is indebted to the Stoic disdain for '

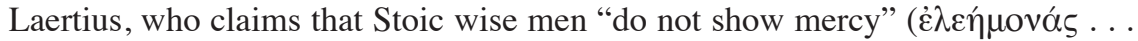

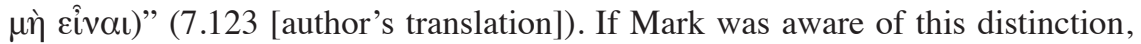
his portrayal of Jesus provides a sharp contrast to Seneca's advice in De clementia and therefore is critical of the philosophical and political discourse pertaining to mercy. Contrary to Seneca's political wisdom and portrayal of the virtuous Roman emperor, Jesus, the son of David, shows unbridled mercy.

${ }^{64}$ E.g., Joel Marcus, "Mark 14:61: ‘Are you the Messiah-Son-of-God?'” NovT 31 [1989] 125-41, at 136; idem, Mark 8-16, 847-51; Paula Fredriksen, From Jesus to Christ: The Origins of the New Testament Images of Jesus (2nd ed.; New Haven: Yale University Press, 2000) 45; and Crispin H. T. Fletcher-Louis, "Jesus as the High Priestly Messiah: Part I," JSHJ 4 (2006) 155-75, at 173.

${ }^{65}$ Marcus, Mark 8-16, 847.

${ }^{66}$ Marcus, Way of the Lord, 137-52.

${ }^{67}$ For instance, while Braund acknowledges that there is no Greek equivalent to clementia, she

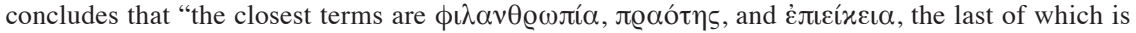
the usual Greek translation of the Latin word clementia in imperial times" (Seneca, 33). See Adam, "Clementia Principis"; Ann Vasaly, "The Quality of Mercy in Cicero's Pro Murena," in Rome and Her Monuments: Essays on the City and Literature of Rome in Honor of Katherine A. Geffcken (ed. Sheila K. Dickison and Judith P. Hallett; Wauconda, IL: Bolchazy-Carducci, 2000) 447-63. 
Similarly, Jesus's arrest and crucifixion in Mark 15 portrays most powerfully this merciful, serving rulership. As Matera has demonstrated, the theme of Mark 15 "is the 'Kingship of Jesus,' a motif which Mark develops through the six-fold use of 'King' $(15: 2,9,12,18,26,32)$ and the three mockery scenes." ${ }^{68}$ The narrative of Mark has anticipated this motif in numerous ways, but it is only in Mark 15 that Jesus's kingship becomes fully explicit. ${ }^{69}$ Within this context of kingship, Mark portrays Jesus's condemnation before Pilate as serving as a ransom for one undeserving person, Barabbas, the insurrectionist whom Pilate releases in lieu of Jesus (15:6-15). Mark 15, therefore, portrays the narrative fulfillment of Jesus's words in Mark 10:45 that he would give his life as a ransom. Thus, the centurion's public confession in 15:39, "Truly, this man was the son of God" ( $\dot{\alpha} \lambda \eta \theta \hat{\omega} \varsigma$ ovं ó öv $\theta \varrho \omega \pi$ ○ Jesus's crucifixion. This confession, set within a depiction of Jesus's crucifixion redolent of royal undertones, redefines for Mark's readers who a true son of God is - one who gives himself for others. ${ }^{70}$ As Marcus concludes, "Royal garments and crowns rightfully do belong to Jesus, who will show his kingship precisely by not saving himself but by dying on the cross." ${ }^{\prime 1}$

\section{Conclusion}

This article began with Clement's assertion that Mark's Gospel reflects the apostle Peter's preaching to the Roman elite. Peppard suggests that "this testimony encourages us to read Mark not only in light of Roman provenance, but even in light of Roman imperial theology." ${ }^{72}$ While most scholars would rightly question the historical value of Clement's claim that Peter preached to the equestrian classes in Rome, it nonetheless provides a fascinating context for reading the Gospel of Mark, and the ransom saying of Mark 10:45 more specifically. If, as is commonly held, Mark was written for a community of Christ followers in Rome in the late 60s or early 70s of the Common Era, the contrast between Roman political theory, as evidenced by Seneca and other writers, and that of Mark's Jesus, as found in Mark

${ }^{68}$ Matera, Kingship of Jesus, 61. Although Jesus never claims to be a king, the fact that he does not reject the title demonstrates that, as Matera notes, "in some manner (understood by the evangelist and his community) Jesus is King of the Jews and King of Israel" (Kingship of Jesus, 64 [italics in original]). On the mockery within this chapter and its ultimate reversal, see T. E. Schmidt, "Mark 15:16-32: The Crucifixion Narrative and the Roman Triumphal Procession," NTS 41 (1995) 1-18, and Joel Marcus, "Crucifixion as Parodic Exaltation," JBL 125 (2006) 73-87.

${ }^{69}$ Matera, Kingship of Jesus, 5. Matera argues that "Mark has not [to this point] explicitly employed the title 'King' because he carefully reserves it for the moment when there can be no misunderstanding the nature of Jesus' kingship" (Kingship of Jesus, 91).

${ }^{70}$ For the imperial context for the title "son of God," see Tae Hun Kim, "The Anarthrous viò Өعov in Mark 15,39 and the Roman Imperial Cult," Bib 79 (1998) 221-41; Yarbro Collins, "Mark and His Readers;" and Peppard, Son of God, 86-131.

${ }^{71}$ Marcus, "Crucifixion," 74, m notes the discussion of Donald H. Juel, Messiah and Temple: The Trial of Jesus in the Gospel of Mark (SBLDS 31; Missoula, MT: Scholars Press, 1977) 48.

${ }^{72}$ Peppard, Son of God, 90. 
10:42-45, is striking. Within about fifteen years of Seneca's writing of De clementia to the Emperor Nero, a work in which he advocates a political theory in which the many deaths ransom the one life of the Emperor, Mark's Jesus advocates a radically different vision - in which the one Son of Man offers his life as a ransom for the many. But, even if Mark did not write for a community in Rome, it remains likely that his readers, no matter where they lived in the Roman Empire, would connect Mark 10:45 to the broadly disseminated political discourse within which Seneca's De clementia belongs. ${ }^{73}$ If Mark wrote, for instance, in Syria or for a community in Syria, the political theory employed by the Syrian legate, whom the Emperor personally chose, would no doubt have been in continuity with Roman political theory. ${ }^{74}$ Jesus's explicit criticism of gentile rulers in Mark 10:42-45 must be related to the gentile rulers of his day - those making up the system of Roman governance, whether in Rome or elsewhere. In Mark 10:42-45, then, we see an early rulership discourse of the Jesus movement that challenges and rejects the type of rulership advocated by Seneca in De clementia.

\footnotetext{
${ }^{73}$ See Miriam T. Griffin, who argues that Rome functioned as the governmental model throughout the empire ("Urbs Roma, Plebs and Princeps," in Images of Empire [ed.Loveday Alexander; JSOTSup 122; Sheffield: Sheffield Academic Press, 1991] 19-46, at 22). In addition, David Braund details how client kings would generally be educated in Rome, further demonstrating how Roman-style rulership could be ensured throughout the Empire (Rome and the Friendly King: The Character of the Client Kingship [London: Croom Helm, 1984] 9-21).

${ }^{74}$ See Fergus Millar, The Roman Near East, 31 B.C.-A.D. 337 (Cambridge, MA: Harvard University Press, 1990) 27-79.
} 